\title{
Accelerated antibacterial red-carbon dots with photodynamic therapy against multidrug-resistant Acinetobacter baumannii
}

\author{
Weijian Liu ${ }^{1}$, Hua Gu${ }^{1}$, Bei Ran ${ }^{1}$, Wenkai Liu ${ }^{1}$, Wen Sun ${ }^{1,2}$, Dongping Wang ${ }^{1,2}$, Jianjun Du ${ }^{1,2}$, \\ Jiangli Fan ${ }^{1,2^{*}}$ and Xiaojun Peng ${ }^{1}$
}

\begin{abstract}
The emergence of antibiotic resistance in bacteria is a major public-health issue. Synthesis of efficient antibiotic-free material is very important for fighting bacterial infection-related diseases. Herein, red-carbon dots (R-CDs) with a broad range of spectral absorption $(350-700 \mathrm{~nm})$ from organic bactericides or intermediates were synthesized through a solvothermal route. The prepared R-CDs not only had intrinsic antibacterial activities, but also could kill multidrug-resistant bacteria (multidrug-resistant Acinetobacter baumannii (MRAB) and multidrug-resistant Staphylococcus aureus (MRSA)) effectively by generating reactive oxygen species. Furthermore, R-CDs could eliminate and inhibit the formation of MRAB biofilms, while conferring few side effects on normal cells. A unique property of R-CDs was demonstrated upon in vivo treatment of antibiotic-sensitive MRABinduced infected wounds. These data suggested that this novel R-CDs-based strategy might enable the design of nextgeneration agents to fight drug-resistant bacteria.
\end{abstract}

Keywords: antibiotic-free materials, carbon dots, intrinsic antibacterial activities, MRAB biofilm eradication

\section{INTRODUCTION}

A bacterial infection is an acute systemic infection caused by pathogenic bacteria or conditioned pathogens invading the blood circulation to produce toxins and other metabolites [1-4]. Several diseases are associated with bacterial infections: tetanus, scarlet fever, typhoid, brucellosis, bacillary dysentery, pulmonary tuberculosis, and bacterial pneumonia [5-9]. During recent decades, antibiotics have been used to treat bacterial infections [10-12]. However, the long-term and excessive use of antibiotics can lead to multidrug-resistant bacteria, which is an evergrowing threat to public health worldwide [13]. The situation is worsening with the increased difficulty and cost in producing new robust antibacterial agents $[12,14]$.

Acinetobacter baumannii (AB) is a typical Gram-negative bacterium and common opportunistic pathogen. It is distributed widely in hospital environments, especially in intensive care units. Treatment of $\mathrm{AB}$ infection is a significant clinical problem, and excessive use of antibiotics causes the emergence of multidrug-resistant $\mathrm{AB}$ (MRAB) [15]. Besides, a biofilm adherent on the surface of $A B$ can protect it from the interference of the external environment, confers strong resistance to host immune defence, and prevents the permeation of antimicrobial agents, which induces greater resistance to antibiotics than that offered by planktonic bacteria [15]. Meanwhile, most of the bacteria embedded in deep biofilms adopt a dormant lifestyle and are relatively insensitive to antibiotics $[3,16]$. Therefore, the development of novel antimicrobial strategies to combat MRAB infections and eliminate the formed biofilms is urgent.

The rapid development of nanotechnology offers new opportunities to deal with bacterial resistance [17]. Some nanomaterial-based agents (e.g., silver nanoparticles [18], semiconductor nanoparticles [13], antibacterial polypeptides $[19,20]$, graphene oxide [21], noble-metal nanoparticles [22]) have been shown to inhibit bacterial infections or eliminate biofilms through a combination of physical/chemical rupture of bacterial cellular/membrane components, photodynamic therapy (PDT) or photothermal therapy (PTT). Unfortunately, their disadvantages (e.g., synthetic complexity, poor penetration of biofilms, instability, and poor biocompatibility) impede their practical application.

Carbon dots (CDs) are a class of carbon-based fluorescent nanomaterials of size $<10 \mathrm{~nm}$. They have received considerable attention for use in biomedical applications due to their superior optical properties, ease-of-synthesis, excellent biocompatibility, anti-photobleaching effects, and outstanding water solubility [23-26]. For examples, some antibiotics (e.g., ciprofloxacin hydrochloride and metronidazole) have been synthesized as CDs, showing promising bactericidal activities as well as decreasing their drug-resistance [27,28]. The positive charge or functional groups on CDs can highly affect antibacterial properties [29-32]. And more interestingly, some CDs have been reported to display exceptional photodynamic activity for treatment of malignant cancer [23,33-35]. However, most CDs absorb ultraviolet (UV) light and have maximum peaks centred in the blue or green region, which causes severe photodamage to tissues and thus greatly limits their further applications in vivo [36-39]. The CDs with long-wavelength emission have the merits of minimal photodamage, negligible interference from autofluorescence to biological tissues, and deep tissue penetration [40]. Therefore, it is critically important to synthesize red emitting CDs (R-CDs) under long-wavelength excitation.

It has been reported that some aromatic structures can generate efficient conjugated aromatic $\pi$ systems and hydrogen

\footnotetext{
${ }^{1}$ State Key Laboratory of Fine Chemicals, Dalian University of Technology, Dalian 116024, China

${ }^{2}$ Ningbo Institute of Dalian University of Technology, Ningbo 315016, China

* Corresponding author (email: fanjl@dlut.edu.cn)
} 
bonds during dehydration and carbonization, and cause a significant red shift in the absorption of CDs [40-44]. Also, heavy atoms (bromine) doping into $\mathrm{CDs}$ can enhance the probability of intersystem crossing to increase photodynamic efficiency.

With this information in mind, we created R-CDs with a broad range of spectral absorption (350-700 nm) and effective photodynamic activity through a solvothermal synthetic route for the imaging and killing of MRAB in vivo. In these R-CDs, an organic bactericide or intermediate (2,4-dihydroxybenzoic acid and 6-bromo-2-naphthol) were chosen as carbon sources. Also, the reaction temperature $\left(180^{\circ} \mathrm{C}\right)$ was controlled below the decomposition temperature of the carbon sources to retain their antibacterial structure (Scheme 1). Hydroxyl, carboxyl, as well as benzene groups in R-CDs facilitated their interactions with biomolecules within bacteria, such as proteins and nucleic acid. The most significant finding of this work is that the as-prepared long-wavelength R-CDs of ultrasmall size $(3.32 \mathrm{~nm})$ could permeate into bacterial biofilms readily, enter bacteria (MRAB) rapidly and kill deep bacteria effectively based on intrinsic antimicrobial activity. Meanwhile, the R-CDs could generate reactive oxygen species (ROS) upon light irradiation $(590 \mathrm{~nm})$, which accelerated MRAB killing and the eradication of MRAB biofilm. R-CDs had few effects on normal cells. The superior performance of R-CDs was also demonstrated by in vivo treatment of antibiotic-sensitive MRAB-induced infected wounds in mice. This novel strategy based on R-CDs might be a promising approach for the design of next-generation agents to fight drug- resistant bacteria.

\section{EXPERIMENTAL SECTION}

\section{General information and materials}

Luria-Bertani (LB) solid medium powder and LB liquid nutrient medium were obtained from Shanghai Yuanye Bio-Technology Co., Ltd. 2,4-Dihydroxybenzoic acid and 6-bromo-2-naphthol were purchased from Energy Chemicals. 3-(4,5-Dimethyl-2thiazolyl)-2,5-diphenyl-2- $H$-tetrazolium bromide (MTT) and Calcein-AM/propidium iodide (PI) detection kit were supplied by Beyotime Biotechnology Co. (China). Crystal violet (CV) was acquired from Sinopharm Chemical Reagent Co., Ltd. All chemicals were used without any further purification. Human breast cancer cells (MCF-7) and renal fibroblasts cells of Cercopithecus aethiops (COS-7) were bought from the Institute of Basic Medical Sciences (IBMS) of the Chinese Academy of Medical Sciences. The ultrapure water used in all the experiments was purified through a Water Purifier Nanopure water system $(18.3 \mathrm{M} \Omega \mathrm{m})$.

\section{Preparation and characterizations of R-CDs}

The R-CDs were synthesized by a facile solvothermal method. Briefly, 2,4-dihydroxybenzoic acid (154.12 mg, $1 \mathrm{mmol}$ ) and 6bromo-2-naphthol (223.07 mg, $1 \mathrm{mmol}$ ) were dissolved in $15 \mathrm{~mL}$ ethanol solution, and added to a $50-\mathrm{mL}$ Teflon-lined stainless autoclave. The reaction mixture was heated at $180^{\circ} \mathrm{C}$ for $12 \mathrm{~h}$.

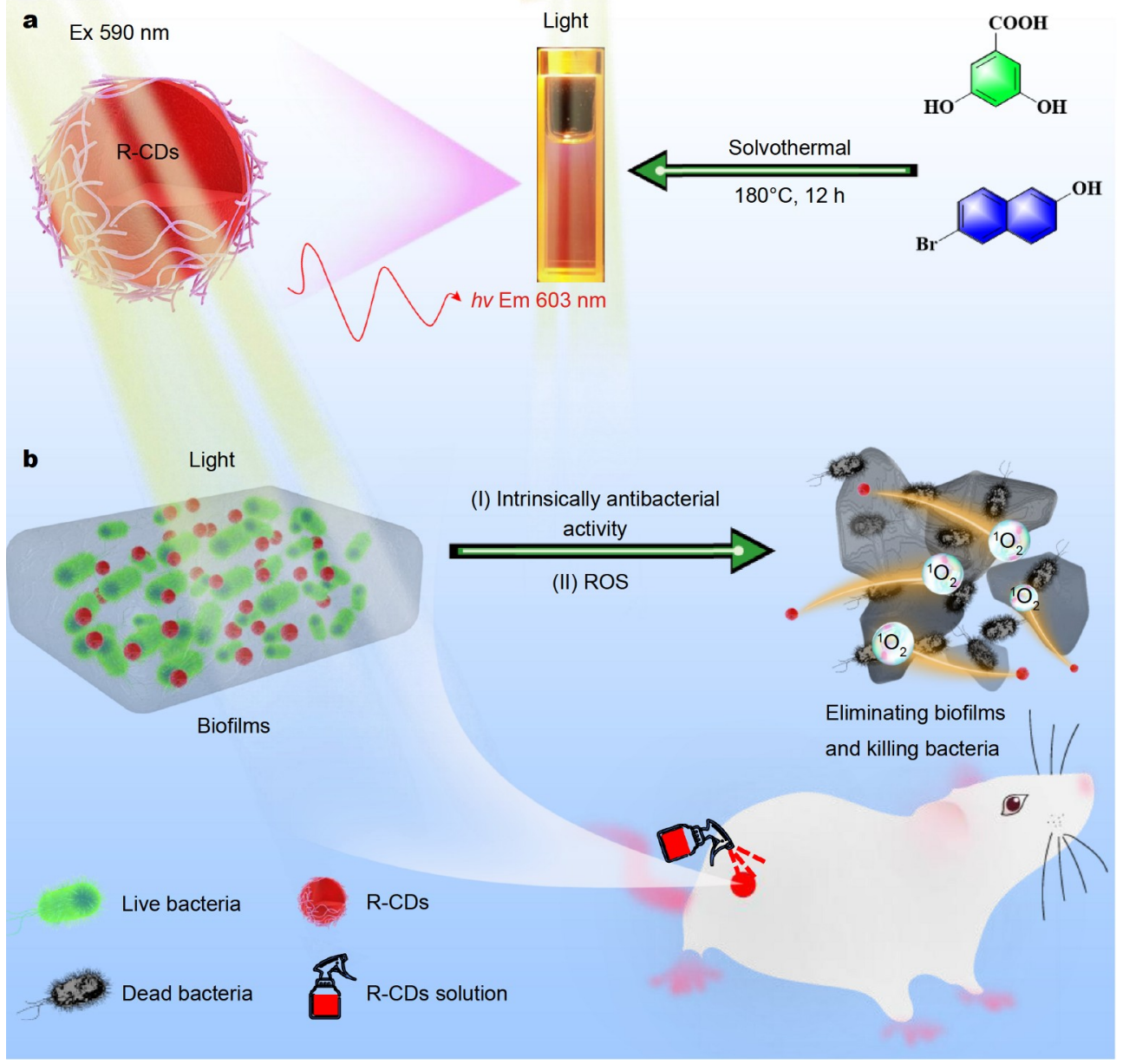

Scheme 1 (a) Synthesis of R-CDs by solvothermal processing. (b) Treatment of MRAB and its biofilms by photoexcited R-CDs. 
After reaction, the suspension was cooled to room temperature, and filtered through an organic filter membrane $(0.22 \mu \mathrm{m})$ for several times. Finally, the dark red solid powder product was obtained by vacuum distillation of the filtrate. R-CDs were well characterized by high resolution transmission electron microscopy (HRTEM, TF30), Fourier transform infrared spectroscopy (FT-IR, Nicolet iN10, Thermo Fisher), X-ray diffraction (XRD), and X-ray photoelectron spectroscopy (XPS). Absorption and emission spectra were performed with an Agilent Cary $60 \mathrm{UV}$ visible (UV-vis) spectrophotometer G6860A(PerkinElmer) and an Agilent Cary Eclipse fluorescence spectrophotometer (Serial No. FL0812-M018), respectively. Confocal laser scanning microscope images were performed on an Olympus FV1000IX81 confocal laser scanning microscope (CLSM, Olympus, Japan).

\section{Bacterial culture and antibacterial assay in vitro}

A single colony of MRAB or multidrug-resistant Staphylococcus aureus (MRSA) were transferred to a liquid LB broth medium $(20 \mathrm{~mL})$ and shaken gently $\left(150 \mathrm{r} \mathrm{min}^{-1}\right)$ at a stationary temperature $\left(37^{\circ} \mathrm{C}\right)$ for $12 \mathrm{~h}$. And then the bacterial suspensions were centrifuged at $5000 \mathrm{rmin}^{-1}$ for $5 \mathrm{~min}$ and washed twice with sterile phosphate buffer solution (PBS, pH 7.4, $0.01 \mathrm{mmol}$ ), and then bacteria were directly diluted with PBS to $10^{6} \mathrm{CFU} \mathrm{mL}{ }^{-1}$. The R-CDs $\left(0,10,20,30,40,50\right.$ and $\left.100 \mu \mathrm{g} \mathrm{mL}^{-1}\right)$ were co-cultured in bacterial suspensions for $15 \mathrm{~min}$ or the suspension was further irradiated by $590-\mathrm{nm}$ light $\left(30 \mathrm{~mW} \mathrm{~cm}^{-2}\right.$, $15 \mathrm{~min}$ ), respectively. Finally, the bacteria were placed on the solid LB agar plates by a spread plate method and cultured for $24 \mathrm{~h}$ at a constant-temperature incubator $\left(37^{\circ} \mathrm{C}\right)$ before counting the number of the bacteria colonies. Control groups were treated with PBS/light and cultured with same conditions.

MRSA and MRAB were cultured in the $\mathrm{LB}$ medium at $37^{\circ} \mathrm{C}$ on a shaker bed at $150 \mathrm{rmin}^{-1}$ for $16 \mathrm{~h}$, respectively. Then the obtained bacterial suspensions were directly diluted to $1 \times$ $10^{6} \mathrm{CFU} \mathrm{mL}{ }^{-1}$. The suspensions $(100 \mu \mathrm{L})$ were added into 96-well plates. Different doses of R-CDs were added into the suspensions, resulting in final concentrations of R-CDs of $0,4,8,16,32$, $64,128,256 \mu \mathrm{g} \mathrm{mL}^{-1}$, respectively. The suspensions were then incubated at $37^{\circ} \mathrm{C}$ for $18 \mathrm{~h}$. Each concentration was prepared and measured in triplicate, and all experiments were repeated at least twice in parallel. The minimum inhibitory concentration (MIC) of R-CDs was the concentration at which growth cannot be observed with the naked eyes.

\section{Drug resistant stimulation study}

Drug resistance of bacterial cells was induced by treating repeatedly with $\mathrm{R}-\mathrm{CDs}[20,45]$. The bacterial suspension was incubated with R-CDs $\left(30 \mu \mathrm{g} \mathrm{mL}{ }^{-1}\right)$ at $37^{\circ} \mathrm{C}$ for $15 \mathrm{~min}$, and then the bacterial solution $(100 \mu \mathrm{L})$ was spread over a solid culture plate. After overnight incubation, the number of colonies was counted. Then, the surviving colonies were re-cultured in a liquid LB broth medium $(20 \mathrm{~mL})$ for $12 \mathrm{~h}$ and incubated with $\mathrm{R}$ CDs for $15 \mathrm{~min}$, and the number of the bacteria colonies was counted again. The process was repeated for nine times.

\section{Live/dead bacterial staining assay}

Live and dead cell staining experiments were performed by the commercial dye kit Calcein AM/PI. The pre-treated bacterial suspensions $\left(1 \mathrm{~mL}, 10^{8} \mathrm{CFU} \mathrm{mL}^{-1}\right)$ were stained by Calcein-AM $\left(2 \mathrm{mmol} \mathrm{L}^{-1}, 1 \mu \mathrm{L}\right)$ and PI $\left(1.5 \mathrm{mmol} \mathrm{L}^{-1}, 2 \mu \mathrm{L}\right)$ for $30 \mathrm{~min}$ in dark. Then, the suspensions were centrifuged at $5000 \mathrm{r} \mathrm{min}^{-1}$ for $5 \mathrm{~min}$ and washed with sterile PBS buffer several times. Finally, a laser scanning microscope (Olympus FV1000-IX81) was performed to observe the live/dead cells.

\section{Detection of total ROS within the bacteria}

The total ROS within the bacteria was detected by using an ROS assay kit, 2',7'-dichlorofluorescin diacetate (DCFH-DA). The fresh bacterial suspensions $\left(1 \mathrm{~mL}, 10^{8} \mathrm{CFU} \mathrm{mL}{ }^{-1}\right)$ were divided into four groups, (I) PBS, (II) light, (III) R-CDs, (IV) R-CDs + light and cultured for $15 \mathrm{~min}$ at a constant-temperature incubator $\left(37^{\circ} \mathrm{C}\right)$. Then, the bacterial suspensions were centrifuged at $5000 \mathrm{r} \mathrm{min}^{-1}$ for $5 \mathrm{~min}$ and washed twice with sterile PBS buffer. Then, DCFH-DA $\left(10 \mathrm{mmol} \mathrm{L}^{-1}, 1 \mu \mathrm{L}\right)$ was added to the four groups and co-cultured for $20 \mathrm{~min}$, respectively. The groups (II, IV) were irradiated with $590-\mathrm{nm}$ light $\left(30 \mathrm{~mW} \mathrm{~cm}^{-2}, 15 \mathrm{~min}\right)$. The suspensions were centrifuged at $5000 \mathrm{r} \mathrm{min}^{-1}$ for $5 \mathrm{~min}$ and rinsed twice with sterile PBS buffer to remove the excess DCFHDA. Finally, the suspensions were dropped into a cell culture dish to be imaged with an FV1000-IX81 confocal laser scanning microscope (Olympus, $\lambda_{\mathrm{ex}}: 488 \mathrm{~nm}, \lambda_{\mathrm{em}}: 500-540 \mathrm{~nm}$ ).

\section{Preparation of bacteria samples for SEM}

The morphology of bacteria of the four groups was obtained by scanning electron microscopy (SEM) [46,47]. The bacterial suspensions of the four groups were collected and fixed with $2.5 \%$ glutaraldehyde for $4 \mathrm{~h}$ in refrigerator $\left(4^{\circ} \mathrm{C}\right)$, followed by dehydration using sequential treatment with ethanol solution $(20 \%, 40 \%, 60 \%, 80 \%$, and $100 \%)$ for $30 \mathrm{~min}$, respectively. Then, the bacterial suspension was dropped onto super-thin carbon films, and dried at room temperature for $12 \mathrm{~h}$, sprayed with platinum for SEM.

\section{Characterization of biofilm morphology by CLSM}

MRAB suspension $\left(2 \mathrm{~mL}, 10^{8} \mathrm{CFU} \mathrm{\textrm {mL } ^ { - 1 } )}\right.$ was placed in a cell culture dish and cultured in an incubator $\left(37^{\circ} \mathrm{C}, 48 \mathrm{~h}\right)$. After the bacterial biofilms were formed, they were respectively treated

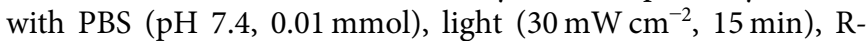
CDs $\left(150 \mu \mathrm{g} \mathrm{mL}^{-1}\right)$, or R-CDs + light $\left(30 \mathrm{~mW} \mathrm{~cm}^{-2}, 15 \mathrm{~min}\right)$ for another $12 \mathrm{~h}$. Subsequently, the suspended medium was discarded and the biofilms were rinsed gently twice with sterile PBS buffer without destroying them. Then the biofilms were treated with Calcein-AM $\left(2 \mathrm{mmol} \mathrm{L}^{-1}, 1 \mu \mathrm{L}\right)$ and PI $\left(1.5 \mathrm{mmol} \mathrm{L}^{-1}, 2 \mu \mathrm{L}\right)$ for $30 \mathrm{~min}$ in dark and then rinsed gently twice to remove excess dye. Finally, the three-dimensional (3D) model of bacterial biofilm was acquired by a laser scanning microscope.

\section{Determination of biofilm biomass by $\mathrm{CV}$ assay}

The fresh MRAB $\left(200 \mu \mathrm{L}, 10^{8} \mathrm{CFU} \mathrm{mL}^{-1}\right)$ was placed in a 96 -well plate and cultured in a constant-temperature incubator $\left(37^{\circ} \mathrm{C}\right.$, $48 \mathrm{~h})$. R-CDs with different concentrations were placed in the wells and incublated at $37^{\circ} \mathrm{C}$ for $4 \mathrm{~h}$. Then the 96-well plate were treated with or without $590-\mathrm{nm}$ light irradiation $\left(30 \mathrm{~mW} \mathrm{~cm}^{-2}\right.$, $15 \mathrm{~min}$ ). After $4 \mathrm{~h}$, the supernatant was gently sucked out and the biofilms were rinsed several times with sterile PBS buffer to remove suspended bacteria. The bacterial biofilms were fixed with $2.5 \%$ glutaraldehyde for $20 \mathrm{~min}$. Then the CV assay solution $(0.1 \%, 150 \mu \mathrm{L})$ was added to stain the biofilm for $30 \mathrm{~min}$, followed by rinsing gently several times with sterile PBS buffer without destroying the established biofilm. The images of residual biofilms were catched using mobile phone (Oppo r15). 
After the addition of $95 \%$ ethanol $(200 \mu \mathrm{L})$ to dissolve the $\mathrm{CV}$, the optical density at $590 \mathrm{~nm}\left(\mathrm{OD}_{590}\right)$ was obtained by a microplate reader. The relative biofilm biomass is calculated by the following equation (Equation (1)).

Relative biofilm biomass (\%)

$=\left[1-\mathrm{OD}_{590 \text { (Sample) }} / \mathrm{OD}_{590(\text { Control })}\right] \times 100$,

where $\mathrm{OD}_{590 \text { (Control) }}$ is the optical density of the solution at $590 \mathrm{~nm}$ for sterile PBS-treated bacterial suspension $[15,48,49]$.

\section{Cell viability assay}

COS-7 cells were incubated in 90\% Dulbecco's modified Eagle medium (Gibico) supplemented with 10\% fetal bovine serum (FBS) (Gibico) and $1 \%$ antibiotics $\left(100 \mathrm{U} \mathrm{mL}^{-1}\right.$ penicillin and $100 \mu \mathrm{g} \mathrm{mL}^{-1}$ streptomycin, Hyclone) in an atmosphere of $37^{\circ} \mathrm{C}$ and $5 \% \mathrm{CO}_{2}[33,50,51]$. COS-7 cells were cultured in 96-well plates with the density of $5 \times 10^{3}$ cells per well and incubated for $24 \mathrm{~h}$. The cells were incubated with R-CDs $(0,10,20,30,40,50$, and $100 \mu \mathrm{g} \mathrm{mL}^{-1}$ ) for $12 \mathrm{~h}$ in dark. For the light group, the cells were incubated with various concentrations of R-CDs for $12 \mathrm{~h}$, and then exposed to $590-\mathrm{nm}$ light $\left(30 \mathrm{~mW} \mathrm{~cm}^{-2}\right)$ for $15 \mathrm{~min}$. The MTT $\left(5 \mathrm{mg} \mathrm{mL}^{-1}, 100 \mu \mathrm{L}\right)$ were added to each well, and incubated for another $4 \mathrm{~h}$. After that, the MTT were replaced by dimethyl sulfoxide (DMSO, $200 \mu \mathrm{L}$ each well), and $\mathrm{OD}_{570 \mathrm{~nm}}$ and $\mathrm{OD}_{630} \mathrm{~nm}$ were recorded by a microplate reader (SpectraMax M2e). The cell viability was calculated by the following formula (Equation (2)):

Cells viability $(\%)$

$$
=\left(\mathrm{OD}_{570}-\mathrm{OD}_{630}\right)_{\mathrm{R}-\mathrm{CDs}} /\left(\mathrm{OD}_{570}-\mathrm{OD}_{630}\right)_{\text {control }} \times 100 \text {. }
$$

\section{Wound healing evaluation}

All the animal experiments involved in this work were carried out upon approval by the Animal Experiment Ethics Committee of Dalian University of Technology. Female BALB/c mice (8 weeks, 16-20 g) were purchased from Changsheng Biological Technology Co., Ltd. (Changchun, China). For establishing the wound infection model, a round wound (diameter: ca. $8.0 \mathrm{~mm}$ ) on the back of the mouse was created, and then $100 \mu \mathrm{L}$ of MRAB suspension $\left(10^{8} \mathrm{CFU} \mathrm{\textrm {mL } ^ { - 1 } )}\right.$ was injected to the local wound. After $24 \mathrm{~h}$, the mice were randomly divided into five groups with four mice in each group: (I) PBS, (II) light, (III) R-CDs $\left(150 \mu \mathrm{g} \mathrm{mL}^{-1}\right)$, (IV) R-CDs $\left(150 \mu \mathrm{g} \mathrm{mL}^{-1}\right)+$ light, (V) polymyxin B $\left(150 \mu \mathrm{g} \mathrm{mL}^{-1}\right)$. Subsequently, $100 \mu \mathrm{L}$ of PBS or R-CDs $\left(150 \mu \mathrm{g} \mathrm{mL}^{-1}\right)$ solution was sprayed to the local wound. After $30 \mathrm{~min}$, the wounds in the light irradiation groups were exposed to $590-\mathrm{nm}$ light $\left(30 \mathrm{~mW} \mathrm{~cm}^{-2}\right)$ for $15 \mathrm{~min}$. The wound diameter and the body weight were measured every three days. After nine days of treatments, all the mice were sacrificed, and the major organs were excised for hematoxylin-eosin (H\&E) staining.

\section{RESULTS AND DISCUSSION}

\section{Synthesis and characterizations of R-CDs}

To endow R-CDs with intrinsic antimicrobial ability, an organic bactericide or intermediate (2,4-dihydroxybenzoic acid and 6bromo-2-naphthol) were chosen as precursors. A solvothermal method was processed for $12 \mathrm{~h}$ at $180^{\circ} \mathrm{C}$ to synthesize the R-CDs (Scheme 1a). As indicated by the HRTEM image, the obtained $\mathrm{R}-\mathrm{CD}$ s showed a spherical-like structure with an average dia- meter of $3.31 \mathrm{~nm}$ (Fig. S1a, b). As shown in Fig. S2, the prepared $\mathrm{R}$-CDs are well dispersed from each other after 17 days, indicating that the material is stable. The obvious crystal-lattice stripes of R-CDs could be observed from the HRTEM image (Fig. 1a). XRD pattern showed a broad diffraction peak $(2 \theta)$ at $21.24^{\circ}$, which is consistent with the (001) lattice spacing of graphitic-like carbon-based materials and suggests that the precursors were partially carbonized into R-CDs (Fig. 1b). FT-IR (Fig. S1d) and XPS (Fig. 1d-g) demonstrated that bromine was incorporated in the obtained R-CDs. High-resolution $\mathrm{Br} 3 \mathrm{~d}$ spectrum revealed that bromine was present in the form of $\operatorname{Br} 3 \mathrm{~d}_{5 / 2}(69.96 \mathrm{eV})$ and $\mathrm{Br} 3 \mathrm{~d}_{3 / 2}(71.0 \mathrm{eV})$, which suggested the same result as well (Fig. $1 \mathrm{~g}$ ).

The UV-vis spectrum of R-CDs displayed broad absorption from UV to near-infrared. The dominant absorption (500$700 \mathrm{~nm}$ ) revealed the $\pi-\pi^{*}$ transition, which was attributed to the $\mathrm{C}=\mathrm{C}$ bond (Fig. 1c). Upon excitation at different wavelengths, the R-CDs emitted fluorescence at $\sim 603 \mathrm{~nm}$ and the absolute fluorescence quantum yield was measured to be $15.3 \%$, indicating that their fluorescence processes were dominated by uniform emissive states (Fig. S1c). Meanwhile, we used 1,3diphenylisobenzofuran (DPBF) as a probe to test the ${ }^{1} \mathrm{O}_{2}$ generation capacity of R-CDs [33]. Irradiation of a solution containing R-CDs and DPBF with 590-nm light led to an apparent decrease in the absorbance intensity of DPBF $\left(\lambda_{\mathrm{abs}}=\right.$ $415 \mathrm{~nm}$ ) over a period of $12 \mathrm{~min}$ (Fig. 1h), which confirmed that ${ }^{1} \mathrm{O}_{2}$ had been generated. According to the decay curves of DPBF, the ${ }^{1} \mathrm{O}_{2}$ yield of $\mathrm{R}-\mathrm{CDs}$ was calculated to be $3.89 \%$ using methylene blue $(\mathrm{MB})$ as the reference (Fig. 1i and Fig. S1e) $[33,52]$. Moreover, the $\mathrm{ROS}\left({ }^{1} \mathrm{O}_{2},{ }^{\cdot} \mathrm{OH}\right.$ and $\left.\mathrm{O}_{2}{ }^{-\bullet}\right)$ production of $\mathrm{R}-\mathrm{CD}$ s was also demonstrated by electron paramagnetic resonance (Fig. S1f), showing that R-CDs could serve as efficient nano-photosensitizers under light irradiation.

\section{Antibacterial activity of R-CDs in vitro}

To better explore the antibacterial ability of R-CDs in vitro, a typical Gram-positive bacterium (MRSA) and a Gram-negative bacterium (MRAB) were chosen. We documented $>97.5 \%$ bacterial survival under 590-nm light irradiation (Fig. S3a, b), which indicated that light had virtually no influence on the viability of MRAB or MRSA. Under CLSM (Fig. S4), the bacteria showed bright fluorescence upon incubation with R-CDs $\left(20 \mu \mathrm{g} \mathrm{mL}^{-1}\right)$ after $15 \mathrm{~min}$, which indicated that small $\mathrm{R}-\mathrm{CDs}$ could readily enter bacteria. As the concentration of R-CDs increased, the survival of MRAB or MRSA decreased accordingly. For MRAB, when the concentration of R-CDs rose up to $50 \mu \mathrm{g} \mathrm{mL}^{-1}$, only $14.2 \%$ bacteria colonies were present (Fig. S5a, c), but more RCDs (concentration $=100 \mu \mathrm{g} \mathrm{mL}^{-1}$ ) were needed to kill MRSA due to its thicker cell wall (Fig. S5b, d). With prolongation of the incubation time from 0 to $45 \mathrm{~min}$, bacterial survival decreased from $97.7 \%$ to $3.3 \%$ (MRAB) and $7.5 \%$ (MRSA), respectively (Fig. 2b, d). The MIC of MRAB and MRSA was 32 and $64 \mu \mathrm{g} \mathrm{mL}^{-1}$, respectively (Fig. S6). These interesting results revealed that the $\mathrm{R}$-CDs have the intrinsically antibacterial activities. To test the accelerating antibacterial effect of PDT, we fixed the incubation time at $15 \mathrm{~min}$ and then irradiated the bacterial suspensions by light $\left(30 \mathrm{~mW} \mathrm{~cm}^{-2}\right)$ for 5,10 , and $15 \mathrm{~min}$, respectively. Virtually no colonies were found on solid Luria broth agar plates after 15-min irradiation, which showed that PDT could accelerate the killing of MRAB or MRSA completely (Fig. $2 \mathrm{c}, \mathrm{d}$ ). In a drug-resistance simulation study, over 
a

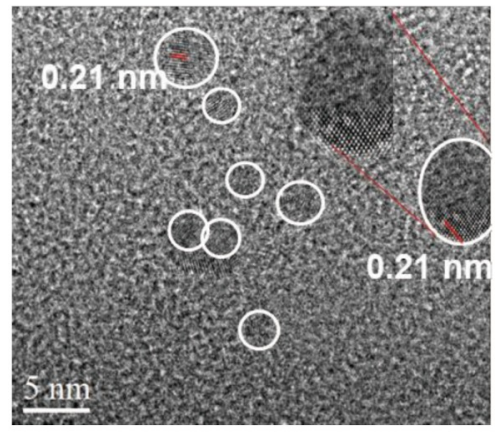

d
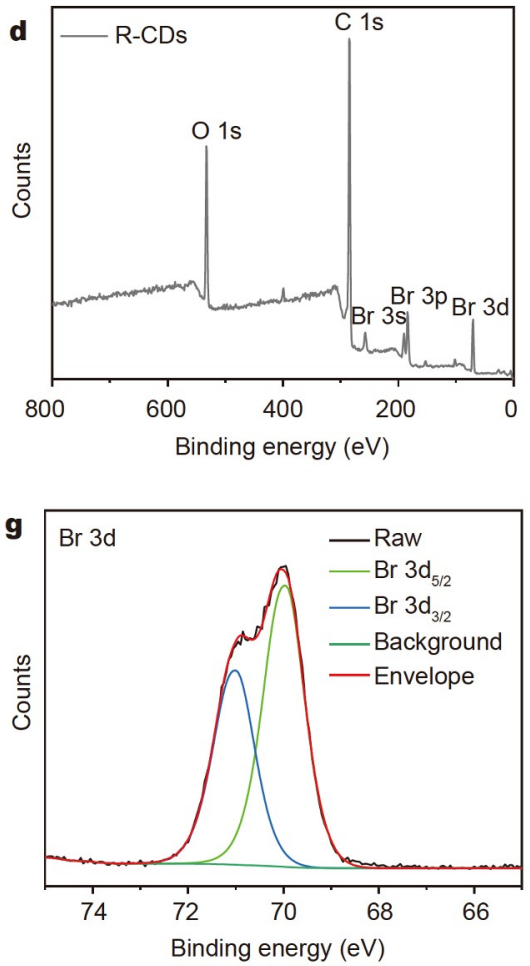
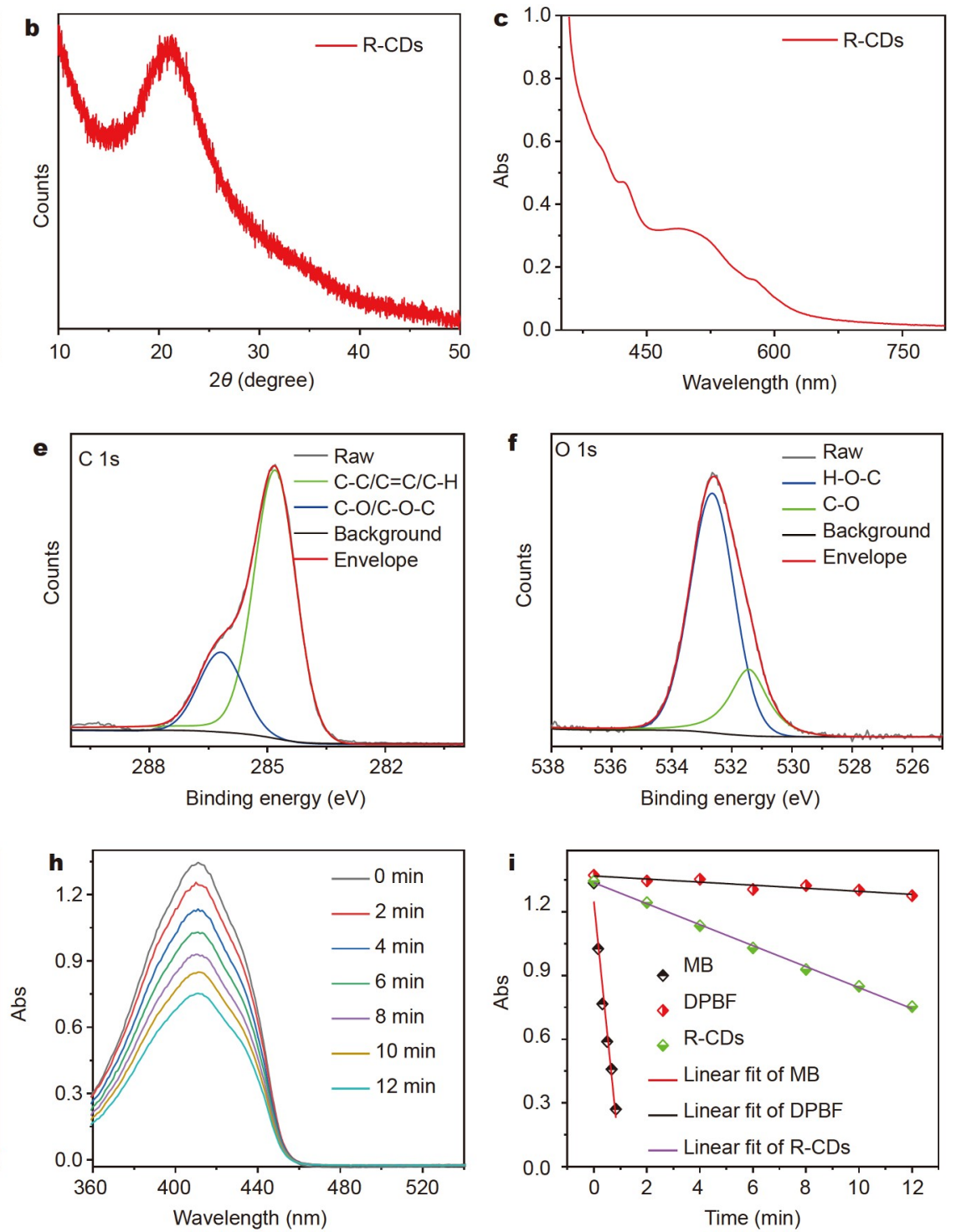

Figure 1 Characterizations of R-CDs. (a) HRTEM image. (b) XRD pattern. (c) UV absorption spectrum. (d) XPS survey scan spectrum. (e) C 1s, (f) O 1s, and (g) Br 3d high-resolution XPS spectra. (h) Decreasing absorbance of DPBF with R-CDs with increasing irradiation time (power density: $8 \mathrm{~mW}^{-2}$ ). (i) Linear fit of absorbance at $413 \mathrm{~nm}$ with $\mathrm{DPBF}, \mathrm{MB}$, and R-CDs under light irradiation (power density: $8 \mathrm{~mW} \mathrm{~cm}^{-2}$ ).

nine cycles, similar antibacterial efficacy was documented without resistance after treatment with R-CDs (Fig. S7). The biocompatibility of R-CDs on normal cells (COS-7) was checked. The imaging results of COS-7 cells confirmed that the low toxicity of R-CDs was found only in the cytoplasm and did not reach the nucleus, which provides a basis for its antibacterial application in vivo (Fig. S8). Therefore, R-CDs could be used to kill bacteria efficaciously.

We wished to ascertain if R-CDs or ROS could destroy the integrity of the cell walls and cell membranes of bacteria. A live/ dead bacterial viability kit was used to stain treated bacteria followed by CLSM $[15,53,54]$. Live bacterial cells showed a green fluorescence signal. Dead bacterial cells were red owing to the intact but damaged membrane [15]. The MRAB in the control groups (PBS or light) maintained membrane integrity to give a green fluorescence signal (Fig. 3a). However, $>90 \%$ of bacteria emitted a red fluorescence signal in the R-CDs group, and even more under light irradiation [48]. Meanwhile, we used the fluorescent probe 2,7-dichlorodifluorescein diacetate to determine the total ROS within bacteria (which could emit green fluorescence in the presence of ROS). Compared with other groups, stronger green fluorescence due to ROS was observed in bacteria incubated with R-CDs after light irradiation (Fig. S9). These results further substantiated the enhanced antibacterial efficiency of R-CDs under light irradiation.

In order to see if any changes in individual cell morphology had occurred after various treatments, SEM was used to observe the MRAB or MRSA cells. The morphology of MRAB or MRSA in the control groups (PBS or light) showed clear edges and their normal forms (full and round) were maintained (Fig. 3b). For MRAB, lipopolysaccharide (LPS) was found covering the outer membrane of the whole body. In contrast, after treatment with R-CDs, LPS fell off the MRAB cell wall, indicating that the bacteria cell was destroyed by R-CDs. Meanwhile, we also found that the cell walls of bacteria collapsed and ruptured with disappearance of the original shape after light irradiation. More- 

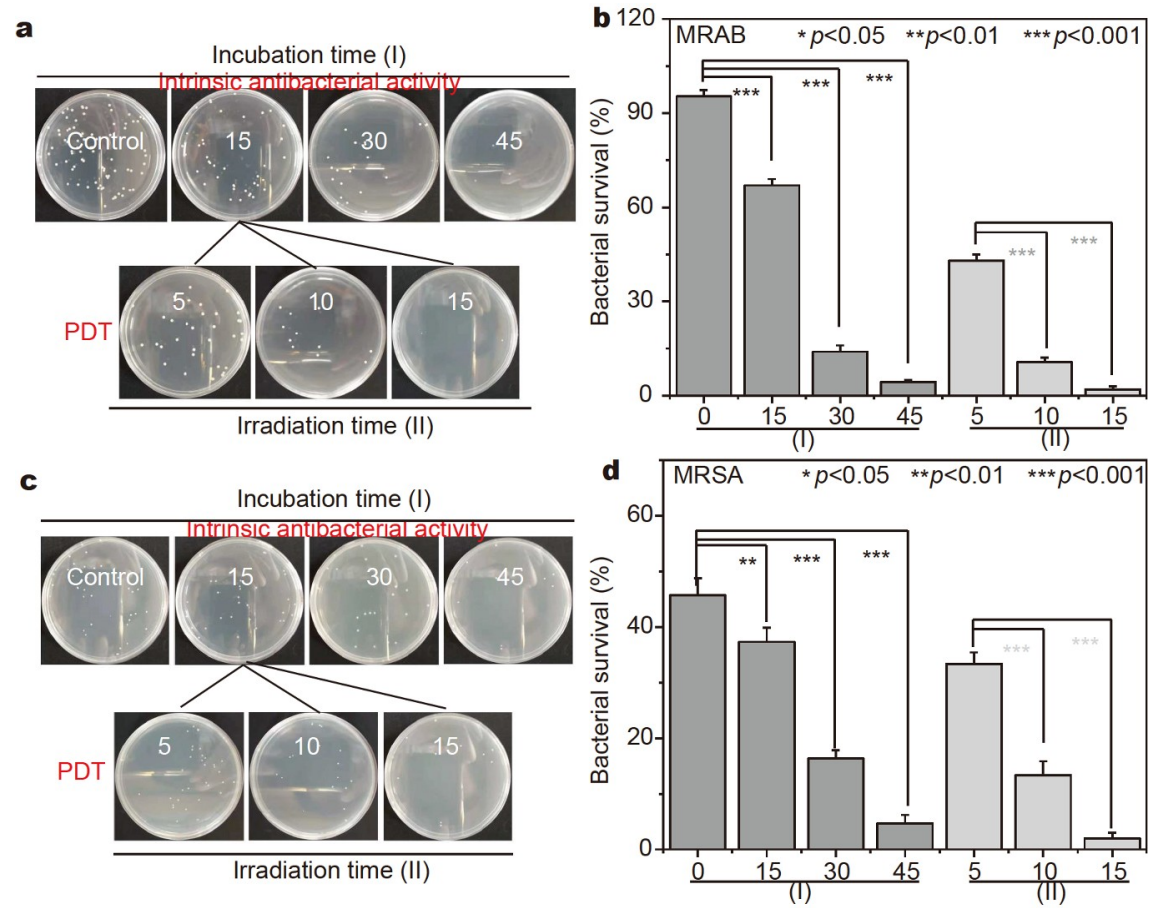

Figure 2 Antibacterial activity of R-CDs $\left(30 \mu \mathrm{gL}^{-1}\right)$ in vitro. (a, c) The optimization of incubation (up) and irradiation time (down) by testing the survival rate of MRAB and MRSA, respectively. (b, d) The bacterial survival of MRAB and MRSA after treatment with different conditions, respectively (590 nm, $30 \mathrm{~mW} \mathrm{~cm}^{-2}$ ). (I) Without light; (II) with light irradiation.

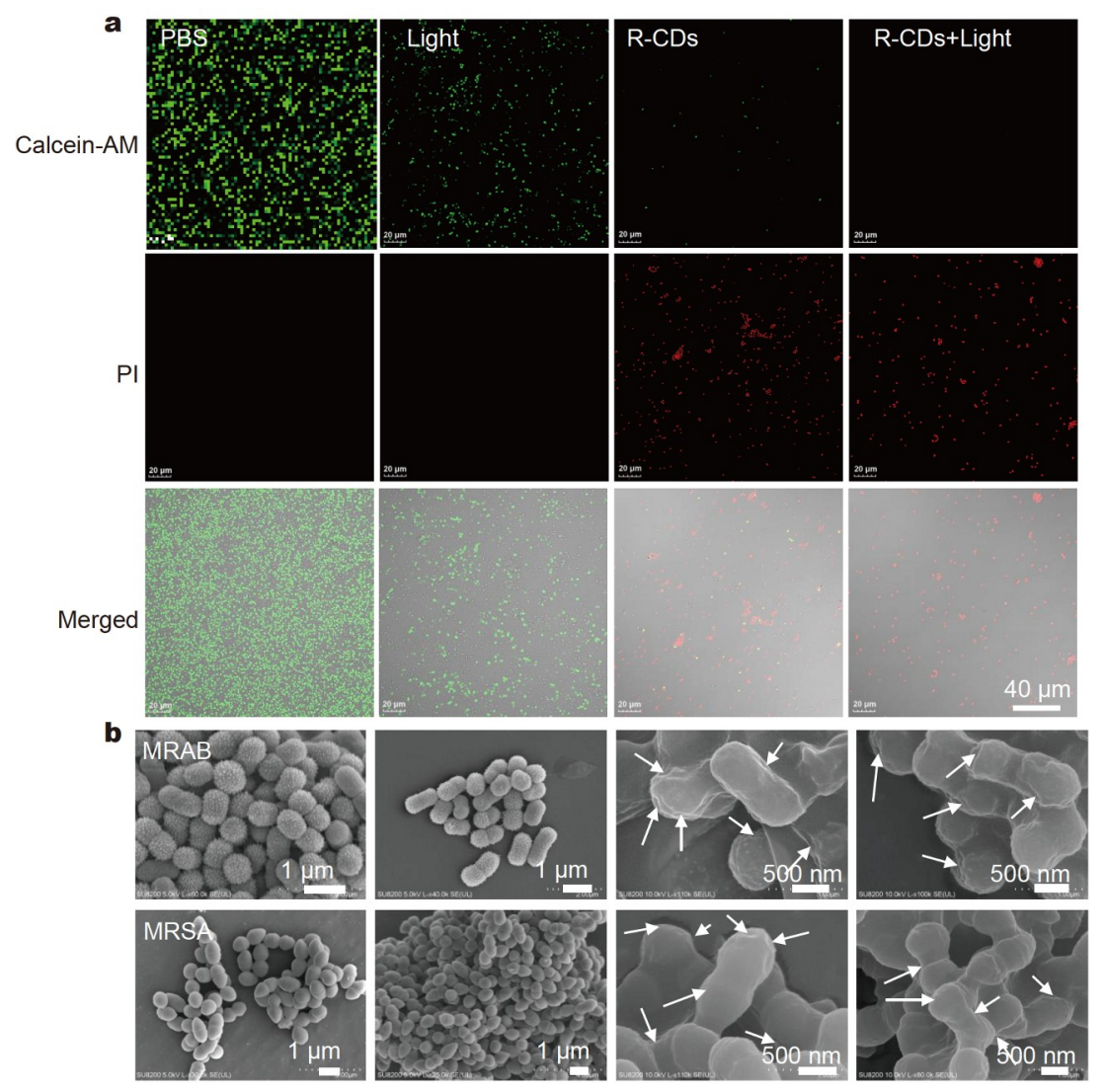

Figure 3 (a) Live/dead MRAB bacterial viability test by confocal laser scanning microscopy (scale bar: $20 \mu \mathrm{m})$. (Calcein-AM: $2 \mu \mathrm{mmol} \mathrm{L}{ }^{-1}, \lambda_{\text {ex }}=488 \mathrm{~nm}$, PI: $1.5 \mathrm{mmol} \mathrm{L}^{-1}, \lambda_{\mathrm{ex}}=561 \mathrm{~nm}$ ). (b) SEM images of MRAB and MRSA after treatment under different conditions. 


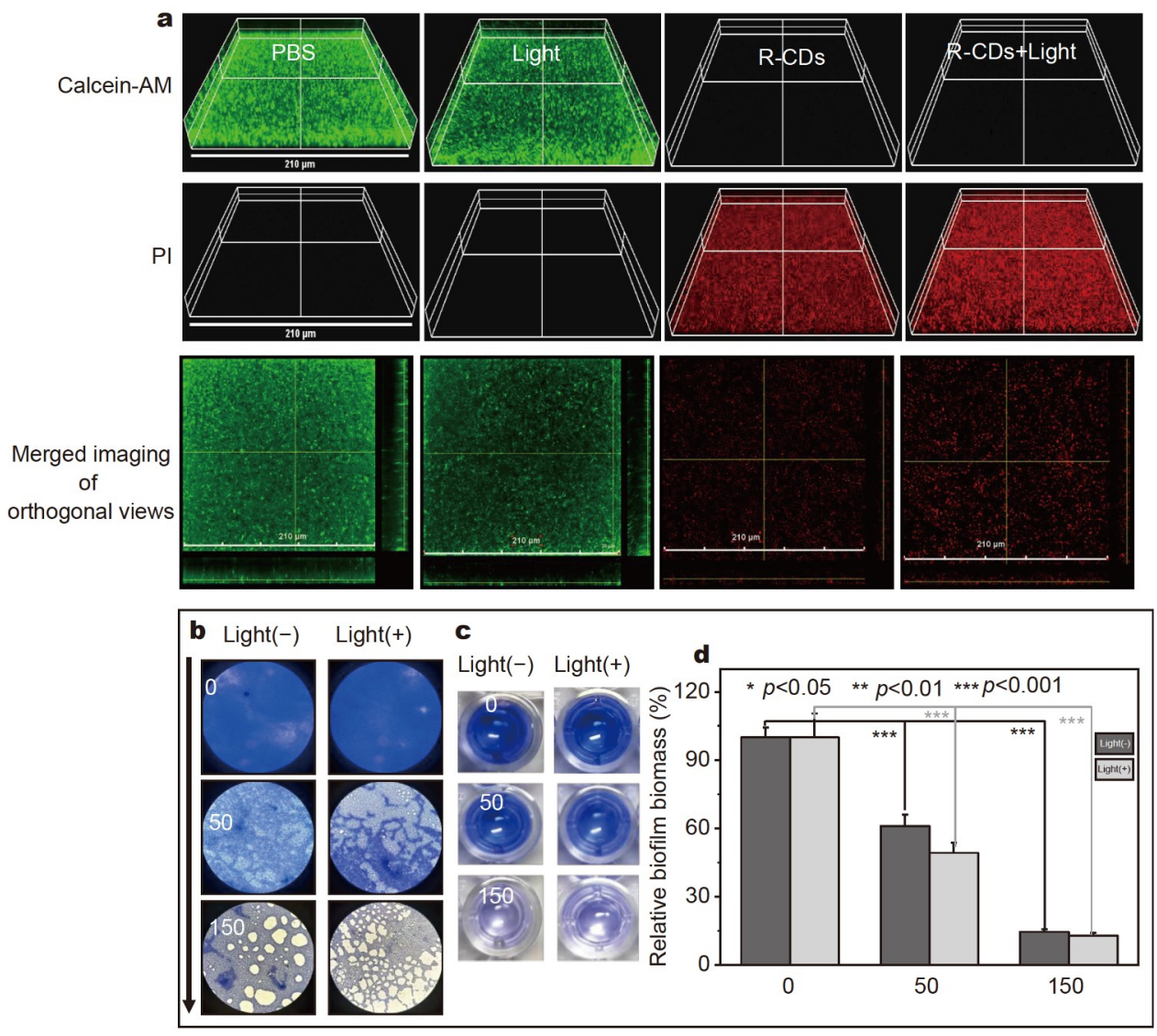

Figure 4 (a) 3D CLSM images of MRAB biofilms labeled by Calcein-AM (green fluorescence)/PI (red florescence) after different treatments (scale bar: $210 \mu \mathrm{m}$ ). (b) Optical-microscopy photographs of CV staining of MRAB biofilms after treatment with various concentrations of R-CDs. (c) CV staining of MRAB biofilms and relative biofilm biomass upon treatments. (d) Relative biofilm biomass after treatment with R-CDs or photoexcited R-CDs.

over, many holes appeared on the bacterial surface. These holes punched by R-CDs would accelerate the permeation of ${ }^{1} \mathrm{O}_{2}$ into the bacterial cytoplasm and cause further damage to MRAB or MRSA.

\section{Inhibition of biofilm formation and biofilm ablation in vitro} More than $60 \%$ of human infectious diseases are attributed to bacterial biofilms, which contribute to their tolerance of antibiotic treatment $[3,54]$. Encouraged by the attractive antibacterial activities of R-CDs, we extended antibacterial tests to eliminate MRAB biofilms in vitro. Live/dead staining was used to evaluate the antibiofilm ability of R-CDs using 3D CLSM. MRAB biofilms presented many red fluorescence spots after incubation with R-CDs or further treatment with light irradiation ( $590 \mathrm{~nm}, 30 \mathrm{~mW} \mathrm{~cm}^{-2}, 15 \mathrm{~min}$ ) (Fig. 4a), which suggested effective penetration of R-CDs within MRAB biofilms. The latter became thinner than those in control groups (PBS or light). In addition, $\mathrm{CV}$ staining was employed to verify the inhibition and elimination of MRAB biofilms. Under an increased concentration of R-CDs, the color of stained biofilms was obviously lightened and biofilms were destroyed accordingly (Fig. $4 \mathrm{~b}$ and Fig. S10a), whereas the biofilms in the control group remained intact and dense [15]. Moreover, under light irradiation, the RCDs-treated group exhibited excellent ablation effects on the biofilms owing to the antibacterial action of PDT (Fig. $4 \mathrm{~b}$ and Fig. S10a). Quantitative analyses (Fig. 4c, d and Fig. S10b, c) revealed that the biomass of biofilms under R-CDs treatment decreased significantly by $\sim 87 \%$ compared with that of the control group. Therefore, R-CDs had considerable potential for the use in MRAB treatment in vivo.

\section{Wound healing and antibacterial activity of R-CDs in vivo} Inspired by the antibacterial activity and biofilm-eradication activity of R-CDs in vitro, we employed antibacterial tests in vivo using a mouse model with MRAB-infected skin wounds (Fig. 5a).

After model building, the infected mice were separated randomly into five groups (four mice per group) and treated under various conditions (Fig. 5a, b). Monitoring of the healing processes of wounds revealed that the rate of wound healing of treatment groups III and IV (began to form a scab at 3rd day) was much faster than that of control groups I, II, and V (at 7th day) and nearly recovered in 9 days (Fig. 5b, d). After 9 days of treatment, all infected skin tissues were harvested, and the bacterial colonies were counted to quantify the antibacterial efficacy of R-CDs. There were few colonies in groups III and IV, whereas many bacterial colonies could be found in control groups I, II, and V (Fig. 5c). Besides, the bodyweight of treated mice was measured, and showed little change while eliminating MRAB biofilms effectively (Fig. 5e). Furthermore, we investigated the safety of R-CDs in vivo through $\mathrm{H} \& \mathrm{E}$ staining of the heart, spleen, liver, lung, and kidney from mice 9 days after treatment. No significant inflammation in any major organ was observed (Fig. 6), which suggested the excellent biocompatibility 
a

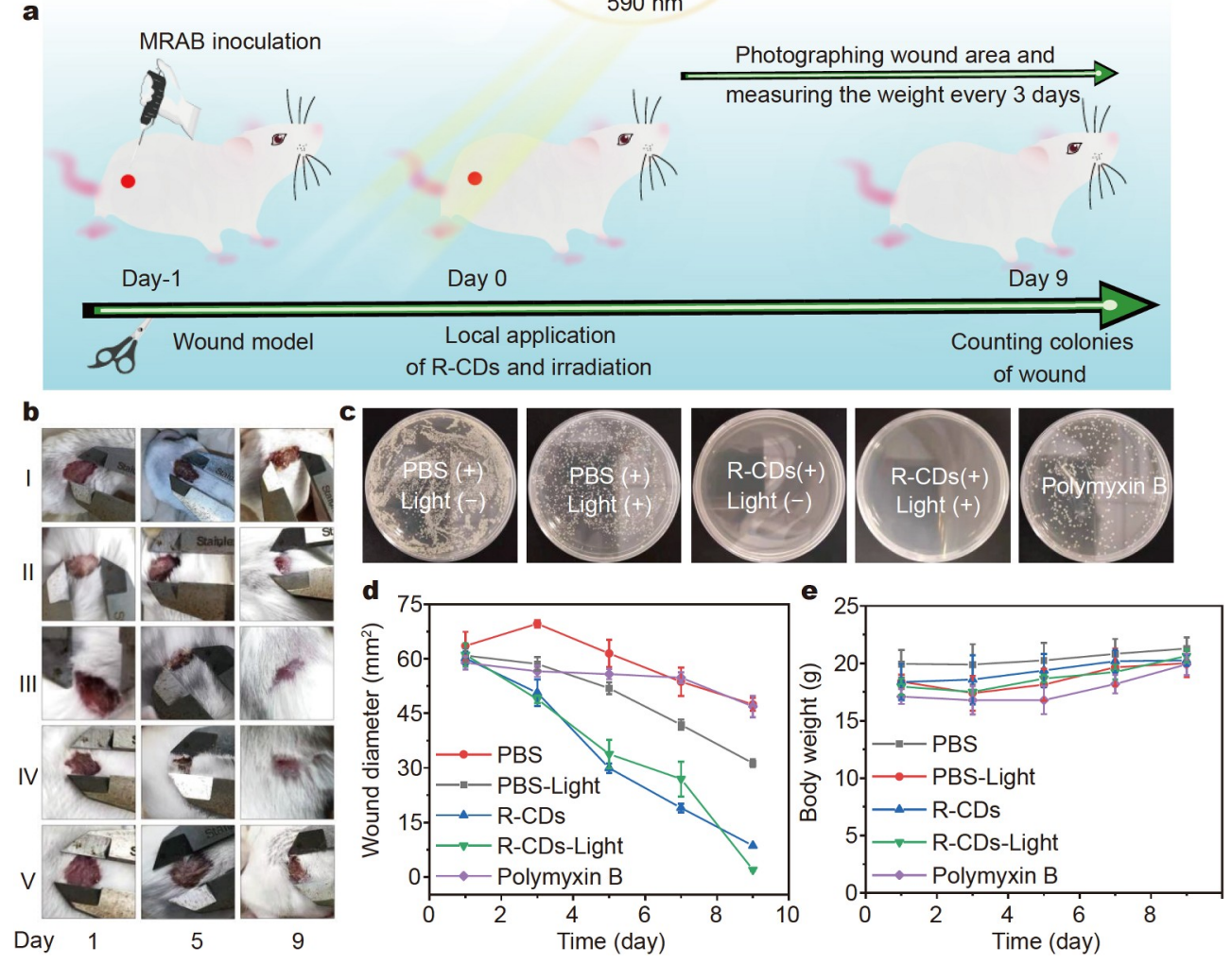

Figure 5 Antibacterial activity in vivo. (a) Model of wound infection on the back of mouse. (b) Time-dependent photographs of wound area on the mouse back with different treatments (scale bar: $10 \mathrm{~mm}$ ). (c) Photographs of bacterial colonies of the wound tissues from different groups 9 days after treatment. (d) Relative wound area of different groups 9 days after treatment. (e) Changes in bodyweight during 9 days after different treatments ((I) PBS, (II) light, (III) R-CDs, (IV) R-CDs + light, (V) polymyxin B).

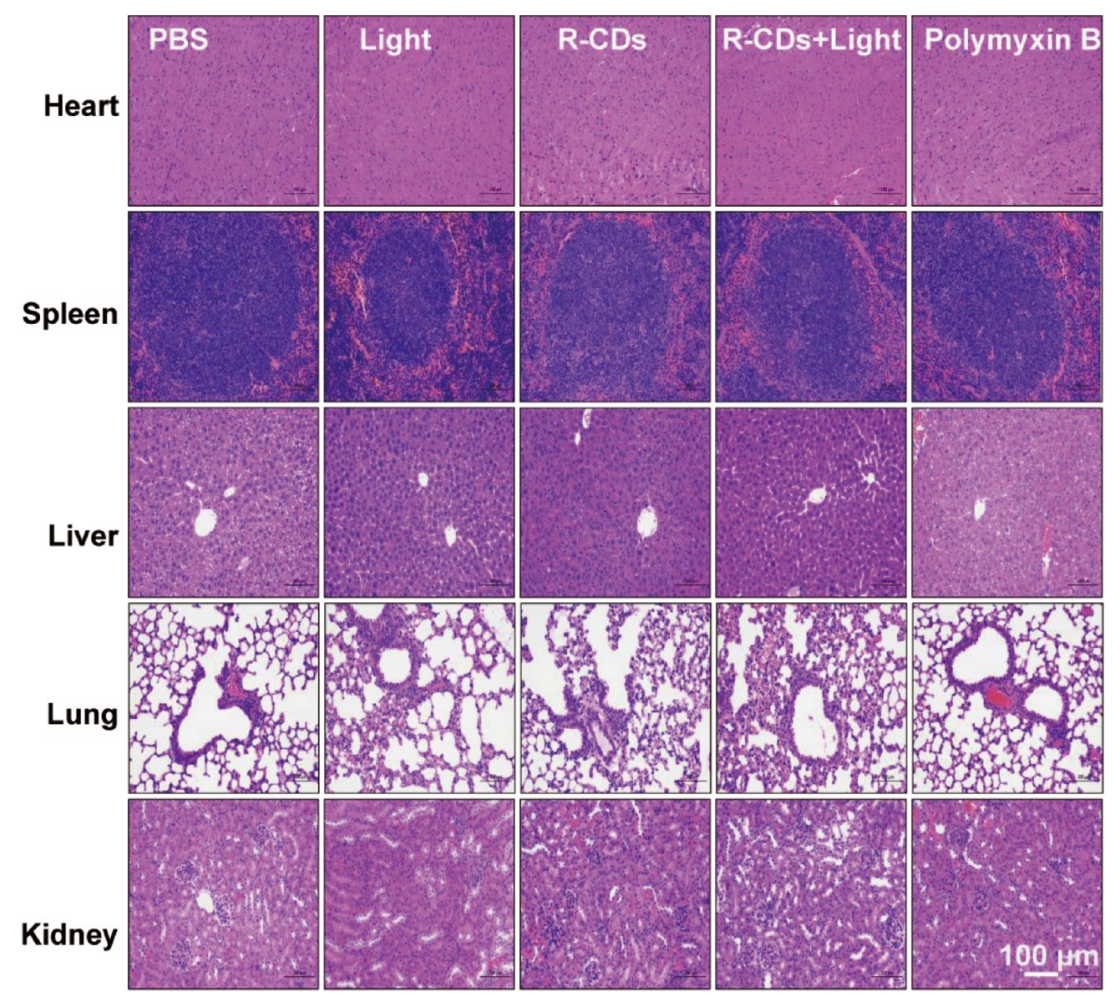

Figure 6 The H\&E staining images of major organs (heart, spleen, liver, lung and kidney) (scale bar: $100 \mu \mathrm{m}$ ). 
and safety of R-CDs.

\section{CONCLUSIONS}

We fabricated an antibacterial system that combined antibacterial activity and antibacterial photodynamic activity to treat MRAB-infected skin wounds. Importantly, the obtained red emissive R-CDs could kill Gram-negative (MRAB) and Grampositive (MRSA) bacteria without microbial drug resistance. When cultured with MRAB-induced biofilms, the ultrasmall-size $\mathrm{R}$-CDs could permeate the whole biofilm rapidly to decompose the matrix of extracellular polymeric substances and kill MRAB deep within the biofilm. Compared with polymyxin $\mathrm{B}$, an in vivo test demonstrated that R-CDs could promote healing in MRABinfected wounds without damaging the normal tissues of mice. This work provides a promising strategy for the design and construction of the next generation of agents to counter drugresistant bacteria.

Received 19 June 2021; accepted 11 August 2021; published online 23 September 2021

1 Hu B, Berkey C, Feliciano T, et al. Thermal-disrupting interface mitigates intercellular cohesion loss for accurate topical antibacterial therapy. Adv Mater, 2020, 32: 1907030

2 Sun Y, Zhao C, Niu J, et al. Colorimetric band-aids for point-of-care sensing and treating bacterial infection. ACS Cent Sci, 2020, 6: 207-212

3 Deng Q, Sun P, Zhang L, et al. Porphyrin MOF dots-based, functionadaptive nanoplatform for enhanced penetration and photodynamic eradication of bacterial biofilms. Adv Funct Mater, 2019, 29: 1903018

4 Bing W, Sun H, Yan Z, et al. Programmed bacteria death induced by carbon dots with different surface charge. Small, 2016, 12: 4713-4718

5 Méndez Y, Chang J, Humpierre AR, et al. Multicomponent polysaccharide-protein bioconjugation in the development of antibacterial glycoconjugate vaccine candidates. Chem Sci, 2018, 9: 2581-2588

6 Saha S, Sajib MSI, Garrett D, et al. Antimicrobial resistance in typhoidal salmonella: Around the world in 3 days. Clin Infect Dis, 2020, 71: S91S95

7 Toerner JG, Rubin D. Advancing new antibacterial drug development for treatment of hospital-acquired and ventilator-associated bacterial pneumonia. Clin Infect Dis, 2016, 63: S37-S38

8 Denning DW, Perlin DS, Muldoon EG, et al. Delivering on antimicrobial resistance agenda not possible without improving fungal diagnostic capabilities. Emerg Infect Dis, 2017, 23: 177-183

9 Li P, Jiang W, Yu Q, et al. Ubiquitination and degradation of GBPs by a Shigella effector to suppress host defence. Nature, 2017, 551: 378-383

10 Ye M, Zhao Y, Wang Y, et al. A dual-responsive antibiotic-loaded nanoparticle specifically binds pathogens and overcomes antimicrobialresistant infections. Adv Mater, 2021, 33: 2006772

11 Xie G, Gao S, Ou J, et al. Conjugating peptides onto 1D rodlike bionanoparticles for enhanced activity against Gram-negative bacteria. Nano Lett, 2021, 21: 1722-1728

12 He X, Yang Y, Guo Y, et al. Phage-guided targeting, discriminative imaging, and synergistic killing of bacteria by AIE bioconjugates. J Am Chem Soc, 2020, 142: 3959-3969

13 Courtney CM, Goodman SM, McDaniel JA, et al. Photoexcited quantum dots for killing multidrug-resistant bacteria. Nat Mater, 2016, 15: 529-534

14 Baker SJ, Payne DJ, Rappuoli R, et al. Technologies to address antimicrobial resistance. Proc Natl Acad Sci USA, 2018, 115: 12887-12895

15 Ran B, Yuan Y, Xia W, et al. A photo-sensitizable phage for multidrugresistant Acinetobacter baumannii therapy and biofilm ablation. Chem Sci, 2021, 12: 1054-1061

16 Zhu Y, Lu J, Han ML, et al. Polymyxins bind to the cell surface of unculturable Acinetobacter baumannii and cause unique dependent resistance. Adv Sci, 2020, 7: 2000704

17 Wang Y, Yang Y, Shi Y, et al. Antibiotic-free antibacterial strategies enabled by nanomaterials: Progress and perspectives. Adv Mater, 2020, 32: 1904106

18 Ivanova A, Ivanova $\mathrm{K}$, Tied A, et al. Layer-by-layer coating of aminocellulose and quorum quenching acylase on silver nanoparticles synergistically eradicate bacteria and their biofilms. Adv Funct Mater, 2020, 30: 2001284

19 Mauro N, Schillaci D, Varvarà $\mathrm{P}$, et al. Branched high molecular weight glycopolypeptide with broad-spectrum antimicrobial activity for the treatment of biofilm related infections. ACS Appl Mater Interfaces, 2018, 10: 318-331

20 Chen Y, Yu L, Zhang B, et al. Design and synthesis of biocompatible, hemocompatible, and highly selective antimicrobial cationic peptidopolysaccharides via click chemistry. Biomacromolecules, 2019, 20: 2230-2240

21 Zou F, Zhou H, Jeong DY, et al. Wrinkled surface-mediated antibacterial activity of graphene oxide nanosheets. ACS Appl Mater Interfaces, 2017, 9: 1343-1351

$22 \mathrm{Hu} \mathrm{D}, \mathrm{Li} \mathrm{H}$, Wang B, et al. Surface-adaptive gold nanoparticles with effective adherence and enhanced photothermal ablation of methicillinresistant Staphylococcus aureus biofilm. ACS Nano, 2017, 11: 93309339

23 Yang W, Ling B, Hu B, et al. Synergistic $N$-heterocyclic carbene/palladium-catalyzed umpolung 1,4-addition of aryl iodides to enals. Angew Chem Int Ed, 2020, 59: 161-166

24 Jiang K, Sun S, Zhang L, et al. Red, green, and blue luminescence by carbon dots: Full-color emission tuning and multicolor cellular imaging. Angew Chem Int Ed, 2015, 54: 5360-5363

25 Wang Z, Fu B, Zou S, et al. Facile construction of carbon dots via acid catalytic hydrothermal method and their application for target imaging of cancer cells. Nano Res, 2016, 9: 214-223

26 Sun YP, Zhou B, Lin Y, et al. Quantum-sized carbon dots for bright and colorful photoluminescence. J Am Chem Soc, 2006, 128: 7756-7757

27 Liu J, Lu S, Tang Q, et al. One-step hydrothermal synthesis of photoluminescent carbon nanodots with selective antibacterial activity against porphyromonas gingivalis. Nanoscale, 2017, 9: 7135-7142

28 Liang G, Shi H, Qi Y, et al. Specific anti-biofilm activity of carbon quantum dots by destroying $P$. gingivalis biofilm related genes. Int $\mathrm{J}$ Nanomed, 2020, Volume 15: 5473-5489

29 Yang J, Zhang X, Ma YH, et al. Carbon dot-based platform for simultaneous bacterial distinguishment and antibacterial applications. ACS Appl Mater Interfaces, 2016, 8: 32170-32181

30 Yang J, Gao G, Zhang X, et al. One-step synthesis of carbon dots with bacterial contact-enhanced fluorescence emission: Fast Gram-type identification and selective Gram-positive bacterial inactivation. Carbon, 2019, 146: 827-839

31 Ju B, Nie H, Zhang X, et al. Inorganic salt incorporated solvothermal synthesis of multicolor carbon dots, emission mechanism, and antibacterial study. ACS Appl Nano Mater, 2018, 1: 6131-6138

32 Zhao $\mathrm{C}, \mathrm{Wu} \mathrm{L}$, Wang $\mathrm{X}$, et al. Quaternary ammonium carbon quantum dots as an antimicrobial agent against Gram-positive bacteria for the treatment of MRSA-infected pneumonia in mice. Carbon, 2020, 163: $70-84$

33 Xu N, Du J, Yao Q, et al. Precise photodynamic therapy: Penetrating the nuclear envelope with photosensitive carbon dots. Carbon, 2020 , 159: $74-82$

34 Sun S, Chen J, Jiang K, et al. Ce6-modified carbon dots for multimodalimaging-guided and single-NIR-laser-triggered photothermal/photodynamic synergistic cancer therapy by reduced irradiation power. ACS Appl Mater Interfaces, 2019, 11: 5791-5803

35 Jia Q, Ge J, Liu W, et al. A magnetofluorescent carbon dot assembly as an acidic $\mathrm{H}_{2} \mathrm{O}_{2}$-driven oxygenerator to regulate tumor hypoxia for simultaneous bimodal imaging and enhanced photodynamic therapy. Adv Mater, 2018, 30: 1706090

36 Chong Y, Ge C, Fang G, et al. Light-enhanced antibacterial activity of graphene oxide, mainly via accelerated electron transfer. Environ Sci Technol, 2017, 51: 10154-10161

37 Bagheri Z, Ehtesabi H, Hallaji Z, et al. Investigation the cytotoxicity and photo-induced toxicity of carbon dot on yeast cell. Ecotoxicol Environ Saf, 2018, 161: 245-250 
38 Jijie R, Barras A, Bouckaert J, et al. Enhanced antibacterial activity of carbon dots functionalized with ampicillin combined with visible light triggered photodynamic effects. Colloids Surfs B-Biointerfaces, 2018, 170: 347-354

39 Dong X, Liang W, Meziani MJ, et al. Carbon dots as potent antimicrobial agents. Theranostics, 2020, 10: 671-686

40 Ding H, Zhou XX, Wei JS, et al. Carbon dots with red/near-infrared emissions and their intrinsic merits for biomedical applications. Carbon, 2020, 167: 322-344

41 Lu S, Sui L, Liu J, et al. Near-infrared photoluminescent polymercarbon nanodots with two-photon fluorescence. Adv Mater, 2017, 29: 1603443

42 Shuang E, Mao QX, Wang JH, et al. Carbon dots with tunable dual emissions: From the mechanism to the specific imaging of endoplasmic reticulum polarity. Nanoscale, 2020, 12: 6852-6860

43 Liu KK, Song SY, Sui LZ, et al. Efficient red/near-infrared-emissive carbon nanodots with multiphoton excited upconversion fluorescence. Adv Sci, 2019, 6: 1900766

44 Zhu Z, Zhai Y, Li Z, et al. Red carbon dots: Optical property regulations and applications. Mater Today, 2019, 30: 52-79

45 Wiradharma N, Khan M, Yong LK, et al. The effect of thiol functional group incorporation into cationic helical peptides on antimicrobial activities and spectra. Biomaterials, 2011, 32: 9100-9108

46 Li H, Huang J, Song Y, et al. Degradable carbon dots with broadspectrum antibacterial activity. ACS Appl Mater Interfaces, 2018, 10: 26936-26946

47 Wu Q, Wei G, Xu Z, et al. Mechanistic insight into the light-irradiated carbon capsules as an antibacterial agent. ACS Appl Mater Interfaces, 2018, 10: 25026-25036

48 Aksoy İ, Küçükkeçeci H, Sevgi F, et al. Photothermal antibacterial and antibiofilm activity of black phosphorus/gold nanocomposites against pathogenic bacteria. ACS Appl Mater Interfaces, 2020, 12: 26822-26831

49 Fang B, Qiu P, Xia C, et al. Extracellular matrix scaffold crosslinked with vancomycin for multifunctional antibacterial bone infection therapy. Biomaterials, 2021, 268: 120603

50 Yang M, Zhang J, Shabat D, et al. Near-infrared chemiluminescent probe for real-time monitoring singlet oxygen in cells and mice model. ACS Sens, 2020, 5: 3158-3164

51 Zhou X, Li H, Shi C, et al. An APN-activated NIR photosensitizer for cancer photodynamic therapy and fluorescence imaging. Biomaterials, 2020, 253: 120089

52 Liu C, Cao Y, Cheng Y, et al. An open source and reduce expenditure ROS generation strategy for chemodynamic/photodynamic synergistic therapy. Nat Commun, 2020, 11: 1735-1743

53 Zhao Z, Yan R, Yi X, et al. Bacteria-activated theranostic nanoprobes against methicillin-resistant Staphylococcus aureus infection. ACS Nano, 2017, 11: 4428-4438

$54 \mathrm{Xu} \mathrm{M}, \mathrm{Hu} \mathrm{Y}$, Xiao Y, et al. Near-infrared-controlled nanoplatform exploiting photothermal promotion of peroxidase-like and oxd-like activities for potent antibacterial and anti-biofilm therapies. ACS Appl Mater Interfaces, 2020, 12: 50260-50274

Acknowledgements This work was supported by the National Natural Science Foundation of China (NSFC, 21925802, 21878039, 21808028, 22022803 and 22078046), the NSFC-Liaoning United Fund (U1908202), and the National Key Research and Development Plan (2018AAA0100301).

\begin{abstract}
Author contributions Liu W designed and performed the experiments and wrote the manuscript. Gu H, Ran B and Liu W were in charge of cell and bacteria culture in the experiments. Sun W, Wang D, Du J and Peng X offered important suggestions and help on how to improve experiments. Fan J directed the whole process in this work and revised the manuscript. All authors contributed to the general discussion.
\end{abstract}

Conflict of interest The authors declare that they have no conflict of interest. version of the paper.

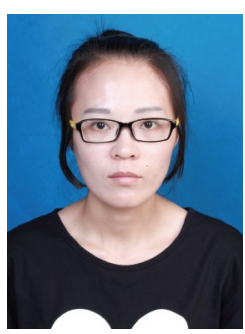

Weijian Liu received his BE degree from Qingdao Agricultural University in 2015. Now, she is a $\mathrm{PhD}$ candidate under the supervision of Prof. Jiangli Fan at the State Key Laboratory of Fine Chemicals, Dalian University of Technology. Currently, her research interests focus on the synthesis of carbon dots and their antibacterial application.

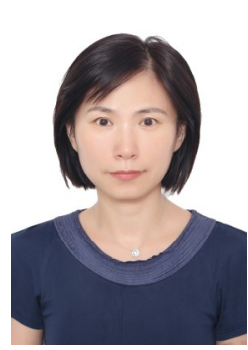

Jiangli Fan received her $\mathrm{PhD}$ from Dalian University of Technology (China) in 2005. In 2010, she attended the University of South Carolina as a visiting scholar. She is currently a professor at the State Key Laboratory of Fine Chemicals, Dalian University of Technology. Her research is focused on fluorescent dyebased probes and their biological applications.

\section{光动力疗法加速抗菌碳点对多耐药鲍曼不动杆菌的 治疗}

刘卫俭 ${ }^{1}$, 顾华 ${ }^{1}$, 由蓓 ${ }^{1}$, 刘 文凯 ${ }^{1}$, 孙文 ${ }^{1,2}$, 王东平 ${ }^{1,2}$, 杜健军 ${ }^{1,2}$, 樊江莉 ${ }^{1,2 *}$, 彭孝军 ${ }^{1}$

摘要 细菌对抗生素产生耐药性是引起公共卫生问题的主要因素. 高 效无抗生素杀菌剂对抗细菌感染相关疾病具有重要意义. 本文采用溶 剂热法, 以有机杀菌剂或合成杀菌剂中间体为碳源, 合成了具有宽吸收 (350-700 nm) 范围的红色荧光发射碳点(R-CDs). 所合成的R-CDs不仅 具有固有的抗菌活性, 还可以通过 $590 \mathrm{~nm}$ 光激发产生活性氧(ROS)有效 杀死多耐药细菌 (多耐药鲍曼不动杆菌 (MRAB) 和多耐药金黄色葡萄球 菌(MRSA)). 此外, R-CDs可有效消除MRAB表面生物膜并进一步抑制 其再生能力, 能够加速由细菌感染的伤口愈合速度, 而对正常细胞的副 作用很小. 因此, 这种非抗生素为碳源的碳点合成新策略为下一代抗耐 药细菌药物的设计提供了参考. 